\title{
STUDENTS' ATTITUDES TOWARDS THE USE OF SMARTPHONE FOR LANGUAGE LEARNING PURPOSES
}

\author{
Ignatius Wisnuwardana \\ Vista Education Surabaya \\ wisnu@vistaeducation.com
}

\begin{abstract}
Utilization of smartphone technology and English language, emerging English language and smartphone technology in non-academic and academic activities for learning purposes, student's perception towards the usage of smartphone apps for English learning purposes, and smartphone apps for enhancing English proficiency are the area where this study is focused, gained from Indonesian High School students. Two hundred participants from $10^{\text {th }}-12^{\text {th }}$ grader of private high schools in Surabaya - Indonesia participated by completing an anonymous questionnaire and 16 participants of each grade were randomly selected and interviewed to gain further understanding towards the findings. The findings indicated smartphone technologies are mostly used by the participants for communication and social media purposes. On the other hand, smartphone is also used incontrovertibly by participants for the certain educational purposes. In addition, learning English via smartphone mobile apps, and diverse types of teenager's online activities were discovered, as well as area of their English skill improvement. The findings suggest that: the students are considerably enthusiastic for using apps to support learning and they also view that smartphones bring substantial potentials and should be optimized for learning through systematic and purposeful activities properly designed for school learning-related activities.
\end{abstract}

Keywords: smartphone, English language learning, leaner autonomy, constructivism

\section{INTRODUCTION}

The increasing availability of mobile technologies such as smartphones and tablets which provide access to multimedia resources and tools (audio, video and chat) undoubtedly holds further potential to support students' language learning (Kukulska-Hulme \& Shield, 2008). The mobile learning phenomenon has led to increased interest in how mobile devices can be used for language learning; many studies and projects have been conducted related to this area, from the use of mobile phones for quiz delivery and vocabulary practice to the use of smartphones and language applications that incorporate flashcards and phrasebooks (GodwinJones, 2011; Stockwell, 2010). Mobile devices network availability and penetration is happening at a dramatic pace in developing countries (Gounder, 2011). This, coupled with the fact that mobile data connection has become more 
affordable, allows for distributed learning anytime and anywhere (Palomo-Duarte, Berns, Dodero, \& Cejas, 2014).

In line with the background of the study and the writer's objectives to achieve, some major research questions are formulated as follows: How do the high school students utilize the technology on smartphone and their daily English language? What are the non-academic and academic activities undertaken by Indonesian high school students in their smartphones for English learning purposes? What are the Indonesian high school students' perceptions about the usage of smartphone for English learning purposes? Which smartphone apps are mostly used by the Indonesian High School students to enhance their individual English skills and language learning competence? What language skills and language components of English do the High School students improve and prefer to learn through smartphone applications?

\section{THEORETICAL REVIEW}

Mobile devices network availability and penetration is happening at a dramatic pace in developing countries (Gounder, 2011). Abbasi and Hashemi (2013) have conducted another study that investigates the effect of using mobile phones on the retention of vocabulary of intermediate EFL learners and the effect of learner's gender in vocabulary retention while using mobile phones. The study concludes that the use of mobile phones by intermediate EFL learners has a significant effect on their vocabulary retention. The study also reveals that gender does not have any effect on learners' vocabulary retention.

In the same vein, Darmi \& Albion (2014) have reviewed studies using mobile phones in language learning contexts. They conclude that mobile phones are accepted by learners of second language learning and that past studies have substantiated their integration to improve language skills and related language areas. They call upon researchers in the field of language learning and acquisition to do more research to examine the integration of mobile learning, especially that mobile phones with recent design and features can be used as learning tools that aid second language learning and language learning acquisition theories. (p. 99).

Mobile phones are only a learning tool to aid language learning; therefore, future studies should also examine its integration in second language acquisition theories applied in the current generation, the GenZers who are kinesthetic learners, and they like to learn by doing and not by being told how to do, or by reading a text. They are interested in graphics, multimedia and connected activities. Due to their inherent nature of multi-tasking, they easily get bored, and so learning tasks should be given to them in small bites. As playing games occupies most of their time, they are quite good at the trial and error method of study. Each time they fail, they only think of the things that they have learnt from their failure, to reach their goal. Du Plessis (2011:28) that "there is a need to explore and understand the elements of technology, social media and social networking that students find so compelling and to incorporate those elements into teaching and learning". This does not only imply integrating technology as part of teaching- learning, but seeking a "creative classroom setup" with unique initiatives that introduce more visual- teaching methods and interesting, quickresult participatory methods. Student-centered learning has power (Du Plessis: 2011:71) and technology advances and social media can further enhance such 
approaches. As the first true digital natives, Gen Zers have never known a world without the internet and mobile devices. Barcelon (2010) identifies generations Y and $\mathrm{Z}$ have both been growing to maturity in the age of the computer. Both have embraced the opportunities provided by an explosion in technology which has created the environment for much of their learning and development.

To summarize, this paper has reviewed studies using smartphones in language learning contexts. Smartphones are accepted by learners of second language and past studies have substantiated their integration to improve language skills and related language areas. Learning can take place in formal or informal settings allowing learners to learn at their own time and anywhere. With recent designs and features of smartphones, future studies on improving the language skills are recommended to keep up with the pace of technology. Other potential areas of research include learning strategies, learner attitude and collaborative learning.

\section{METHOD}

In this study, there were 200 respondents of Senior High School students registered in academic year 2018/2019 randomly selected and then categorized by the following demographics: A total of 200 high students participated in this study out of which majority were female students (52.50\%) with mean age of 16.565 years old. The total number of $52.50 \%$ female students and $47.50 \%$ male students is further explored in the breakdown of: below 15 year-old group: $15.50 \%$ male $16 \%$ female, followed by 15-16 year-old group with $18 \%$ male and $20.50 \%$ female, and the last 17-18 year-old group with $14 \%$ male and $16 \%$ female students.

Table 1: Participants' Individual Demographic Information

\begin{tabular}{|c|c|c|c|c|c|c|c|c|c|}
\hline & & Bel & w 15 & 15- & & $17-$ & & TOT & \\
\hline \multirow{3}{*}{ Sex } & Item & $\mathbf{N}$ & $(\%)$ & $\mathbf{N}$ & $(\%)$ & $\mathbf{N}$ & $(\%)$ & $\mathbf{N}$ & $(\%)$ \\
\hline & Female & 32 & $16.00 \%$ & 41 & $20.50 \%$ & 32 & $16.00 \%$ & 105 & $52.50 \%$ \\
\hline & Male & 31 & $15.50 \%$ & 36 & $18.00 \%$ & 28 & $14.00 \%$ & 95 & $47.50 \%$ \\
\hline \multicolumn{2}{|c|}{ TOTAL } & 63 & $31.50 \%$ & 77 & $38.50 \%$ & 60 & $30.00 \%$ & 200 & $100.00 \%$ \\
\hline
\end{tabular}

\section{Research Instrument for Primary Data 1}

The main method of inquiry used in this study is a five-point and a sixpoint Likert-type questionnaire which was designed by the writer. The questionnaire included three dimensions: First, emerging English language and smartphone technology in non-academic consisting of twelve questions of frequency selection and academic activities for learning purposes consisting of fifteen questions of frequency selection. Second, student's perception on the usage of smartphone for English learning purposes consisting of seventeen questions of a 6-point of Likert scale. Third, smartphone applications for enhancing English proficiency consisting of one table of single preferred option. Thus, for each of the statements in the instrument, participants were required to respond in shortanswer questions, choose one answer on multiple choice questions, choose answers based on Likert scale of Totally Agree, Agree, Slightly Agree, Disagree, 
Slightly Disagree, and Totally Disagree as well as give a rate $1-6$ scale, whilst for the rests of the questionnaire Never, Sometimes, Frequent, and Always are available options to select to establish frequency represented by a rate scale 1-5 for gathering information on the perception or preference about the way the participants utilize their smartphones for the English learning purposes.

\section{Research Instrument for Primary Data 2}

They were gained through recorded improvisational and structured interviews. These two models of interviews were conducted once after the writer gained complete data analysis of the questionnaires. The improvisational interview was used as supplementary data aimed to address the topic Emerging Smartphone Technology and English Language in Daily Lives questionnaire in the primary data one. There were seven participants randomly chosen by the writer to state their responses towards this issue. In addition, another four crucial issues were elevated by the writer for the structured interview given to 10 participants to be used as supplementary data. All were then processed and analyzed in order to investigate the Research Questions 2 and 3. In this study, the interview questions allowed the interview purpose, and were separated into two aspects:

1. Fixed questions: 4 questions are designed in advance.

2. Improvisational questions: some questions are asked by the interviewer according the conversations.

The structured-interview consisting of fixed questions were designed to target the purpose of interview. They were as follows:

Question 1: What do you think are the most important uses of smartphones in the education world for the millennial generation today?

Question 2: To what extent do smartphones have an impact on your English learning?

Question 3: Do you think the role of teachers in schools will still not be replaced by the sophistication of today's smartphones. Why is or isn't that so?

Question 4: Will online learning produce more results than face-to-face learning at school? What is the role of the smartphone in the future?

\section{Validity and Reliability of the Instrument}

To assess the reliability of the instrument, Cronbach's Alpha correlation coefficient was computed. Results obtained from this test indicate the reliability of the instrument since Cronbach's Alpha value was more than (0.60). Table 2 below shows the result. 
Table 2: Reliability of the Questionnaire of the Study

\begin{tabular}{|l|r|}
\hline \#items/questions/components & 17 \\
\hline sum of the item variances & 17.965 \\
\hline variance of Total Score & 62.71 \\
\hline Cronbach's $\alpha$ & 0.758118 \\
\hline
\end{tabular}

\begin{tabular}{|l|l|}
\hline Cronbach's alpha & Internal consistency \\
\hline$a \geq 0.9$ & Excellent \\
\hline $0.9>a \geq 0.8$ & Good \\
\hline $0.8>a \geq 0.7$ & Acceptable \\
\hline $0.7>a \geq 0.6$ & Questionable \\
\hline $0.6>a \geq 0.5$ & Poor \\
\hline $0.5>a$ & Unacceptable \\
\hline
\end{tabular}

\section{Data Collection}

The writer's two sources of primary data were respectively gathered from the questionnaire and through improvisational and structured-interviews. The writer obtained permission of the instructor who taught the three sections of English mentioned above to conduct his study in order to investigate the high school students' attitudes towards the smartphone and the usages in learning English. The participants were requested to state their true responses. The writer also answered all the participants' relevant questions about the questionnaire to ensure that they give authentic responses. While for the secondary data, the writer collected from available literature such as books, research papers, journals, magazine articles, etc. and were supported by primary data collected using a quantitative method of data collection about the impact of the use of smartphone in the classroom.

\section{Analysis of Data}

To organize and summarize all the gathered data in order to increase results' usefulness, the primary and secondary data were analyzed descriptively in quantitative study using a simple a statistical software to determine the mean, percentage, and frequency mode.

\section{FINDINGS AND DISCUSSION}

The aim of this part is to present the analysis of the data collected on the study. The first question of this study aimed to investigate the extent to which Indonesian high school students use their smartphones in the aspect of emerging English language and smartphone technology in both academic and non-academic learning purposes. To answer these fifteen questions of frequency selection, the respondents selected one single answer only determined by their habits in using smartphones either at home or at school. As can be seen in table 3, Teenagers seemed to be a Youtube dependent which can be indicated by 122 respondents or by $61 \%$ frequently accessed and used it at home. 
Table 3: Mobile Apps usage for English learning purposes at home

\begin{tabular}{|c|c|c|c|c|}
\hline \multicolumn{5}{|c|}{ How do you use your English at home? } \\
\hline Item & Never & Seldom & Frequent & Always \\
\hline a. Inputting English keywords in internet web & $\begin{array}{c}11 \\
5.50 \%\end{array}$ & $\begin{array}{c}78 \\
39.00 \%\end{array}$ & $\begin{array}{c}83 \\
41.50 \%\end{array}$ & $\begin{array}{c}28 \\
14.00 \%\end{array}$ \\
\hline b. Internet browsing or surfing to seek information & 7 & 80 & 84 & 29 \\
\hline in English? & $3.50 \%$ & $40.00 \%$ & $42.00 \%$ & $14.50 \%$ \\
\hline c. Writing captions or adding comments in some & 9 & 74 & 92 & 25 \\
\hline social media e.g. Youtube, Facebook, Twitter, & $4.50 \%$ & $37.00 \%$ & $46.00 \%$ & $12.50 \%$ \\
\hline Instagram, Snapehat, Binterest. etc? & & & & \\
\hline d. Checking and replying emails in English? & 45 & 120 & 33 & 2 \\
\hline & $22.50 \%$ & $60.00 \%$ & $16.50 \%$ & $1.00 \%$ \\
\hline e. Listening to English music or English podcast? & 0 & 42 & 113 & 45 \\
\hline & $0.00 \%$ & $21.00 \%$ & $56.50 \%$ & $22.50 \%$ \\
\hline f. Watching Youtube videos or other movie & 1 & 40 & 122 & 37 \\
\hline streaming platforms in English & $0.50 \%$ & $20.00 \%$ & $61.00 \%$ & $18.50 \%$ \\
\hline g. Online bank transactions in English? & 77 & 74 & 43 & 6 \\
\hline & $38.50 \%$ & $37.00 \%$ & $21.50 \%$ & $3.00 \%$ \\
\hline h. Online shopping transactions in English? & 65 & 96 & 33 & 6 \\
\hline & $32.50 \%$ & $48.00 \%$ & $16.50 \%$ & $3.00 \%$ \\
\hline i. Recording, editing, and narrating videos or video & 49 & 112 & 32 & 7 \\
\hline blogs $(y \log s) ?$ & $24.50 \%$ & $56.00 \%$ & $16.00 \%$ & $3.50 \%$ \\
\hline j. Designing, editing pictures in English? & 49 & 102 & 38 & 11 \\
\hline & & & & \\
\hline k. Creating English animation? & 94 & 75 & 30 & 1 \\
\hline & $47.00 \%$ & $37.50 \%$ & $15.00 \%$ & $0.50 \%$ \\
\hline 1. Online chat activities In English? & 9 & 102 & 73 & 16 \\
\hline & $4.50 \%$ & $51.00 \%$ & $36.50 \%$ & $8.00 \%$ \\
\hline
\end{tabular}

While for the academic activity for the English learning purposes, the result in table 4 indicates that the use of smartphone at school is lack of academic activities and the conclusion that can be drawn from this section is that there has not enough attempt made at both an individual or institutional level to optimize the wealth of the educational technological gadgets for activities related to schoolrelated activities.

Table 4. Mobile Apps for English Learning Purposes at School

\begin{tabular}{lllll}
\hline When and how do you use your English at school? & & & \\
\hline Item & Never & Sometimes & Frequent & Always \\
\hline & & & & \\
a. During school lessons & 41 & 113 & 38 & 8 \\
& $20.50 \%$ & $56.50 \%$ & $19.00 \%$ & $4.00 \%$ \\
b. Elsewhere at school & 34 & 111 & 51 & 4 \\
& $17.00 \%$ & $55.50 \%$ & $25.50 \%$ & $2.00 \%$ \\
c. On the way to school e.g. on the car & 58 & 94 & 42 & 6 \\
& $29.00 \%$ & $47.00 \%$ & $21.00 \%$ & $3.00 \%$ \\
d. On the way to go home e.g. on the & 49 & 85 & 56 & 10 \\
car & $24.50 \%$ & $42.50 \%$ & $28.00 \%$ & $5.00 \%$ \\
e. Playing English games during & 63 & 101 & 33 & 3
\end{tabular}




\begin{tabular}{lllll} 
English lesson? & $31.50 \%$ & $50.50 \%$ & $16.50 \%$ & $1.50 \%$ \\
f. Capturing my English Teacher's note & 69 & 78 & 48 & 5 \\
on the whiteboard & $34.50 \%$ & $39.00 \%$ & $24.00 \%$ & $2.50 \%$ \\
g. Reading your English teacher's soft- & 40 & 97 & 58 & 5 \\
file lesson or digital notes & $20.00 \%$ & $48.50 \%$ & $29.00 \%$ & $2.50 \%$ \\
h. Watching your English teachers' & 65 & 101 & 30 & 4 \\
captured lesson? & $32.50 \%$ & $50.50 \%$ & $15.00 \%$ & $2.00 \%$ \\
i. Watching some English instructional & 24 & 103 & 64 & 9 \\
video assignments? & $12.00 \%$ & $51.50 \%$ & $32.00 \%$ & $4.50 \%$ \\
j. Doing English literature searches? & 31 & 95 & 61 & 13 \\
& $15.50 \%$ & $47.50 \%$ & $30.50 \%$ & $6.50 \%$ \\
k. Sharing English notes with your & 27 & 88 & 69 & 16 \\
classmates? & $13.50 \%$ & $44.00 \%$ & $34.50 \%$ & $8.00 \%$ \\
l. Taking photos of your English & 76 & 91 & 31 & 2 \\
projects? & $38.00 \%$ & $45.50 \%$ & $15.50 \%$ & $1.00 \%$ \\
m. Making movies of your English & 55 & 109 & 34 & 2 \\
projects? & $27.50 \%$ & $54.50 \%$ & $17.00 \%$ & $1.00 \%$ \\
n. Designing some English presentation & 44 & 93 & 60 & 3 \\
lessons & $22.00 \%$ & $46.50 \%$ & $30.00 \%$ & $1.50 \%$ \\
o. Doing some English quizzes or & 30 & 94 & 72 & 4 \\
English tests? & $15.00 \%$ & $47.00 \%$ & $36.00 \%$ & $2.00 \%$ \\
\hline
\end{tabular}

\section{Student Perception on Mobile Apps Usage for English Learning Purposes}

In general, the results of the study in table 5 revealed that the participants had a positive attitude toward using mobile phones for educational purposes as they agreed that smartphone usage for educational purposes should be selfmotivated.

Table 5. Student Perception toward Mobile Apps Usage for English Learning Purposes

\begin{tabular}{|c|c|c|c|c|c|c|}
\hline Question Item & TD & D & SD & SA & A & TA \\
\hline $\begin{array}{l}\text { 1. Using smartphones as a study } \\
\text { tool for English language } \\
\text { learning for High School students } \\
\text { is important }\end{array}$ & $\begin{array}{l}8 \\
4.00 \%\end{array}$ & $\begin{array}{l}0 \\
0.00 \%\end{array}$ & $\begin{array}{l}16 \\
8.00 \%\end{array}$ & $\begin{array}{l}59 \\
29.50 \%\end{array}$ & $\begin{array}{l}71 \\
35.50 \%\end{array}$ & $\begin{array}{l}46 \\
23.00 \%\end{array}$ \\
\hline 2. Learning English through & 5 & 5 & 26 & 38 & 72 & 54 \\
\hline $\begin{array}{l}\text { Smartphones can be fun and } \\
\text { interesting if it is done in the } \\
\text { classroom }\end{array}$ & $2.50 \%$ & $2.50 \%$ & $13.00 \%$ & $19.00 \%$ & $36.00 \%$ & $27.00 \%$ \\
\hline 3. Mobile phones will never be & 8 & 10 & 31 & 44 & 63 & 44 \\
\hline $\begin{array}{l}\text { able to replace the role of my } \\
\text { English classroom teacher }\end{array}$ & $4.00 \%$ & $5.00 \%$ & $15.50 \%$ & $22.00 \%$ & $31.50 \%$ & $22.00 \%$ \\
\hline 4. I prefer to have one-on-one & 1 & 12 & 42 & 39 & 65 & 41 \\
\hline $\begin{array}{l}\text { English lesson discussion with } \\
\text { my classmates rather than chat } \\
\text { with them on social media apps }\end{array}$ & $0.50 \%$ & $6.00 \%$ & $21.00 \%$ & $19.50 \%$ & $32.50 \%$ & $20.50 \%$ \\
\hline 5. I feel it is more polite to have & 8 & 7 & 50 & 45 & 58 & 32 \\
\hline one-on-one English lesson & $4.00 \%$ & $3.50 \%$ & $25.00 \%$ & $22.50 \%$ & $29.00 \%$ & $16.00 \%$ \\
\hline
\end{tabular}


discussion with my classroom teachers rather than chat with them on social media apps

6. There is not enough time if I only learn English in the classroom

7. Learning English through smartphones can help the teachers deliver the lessons more engaging and interactively 8. I feel more motivated in learning English through mobile phones

9. I can easily get either tempted or distracted by other things apart the English lesson from if I learn English through smartphones 10. I prefer doing my English school assignments through my $\begin{array}{ll}7 & 10 \\ 3.50 \% & 5.00 \%\end{array}$ 42 47

$3.50 \% \quad 5.00 \% \quad 21.00 \%$

$23.50 \%$ 52 42 2 $1.00 \% \quad 2.00 \%$ 23 64 $26.00 \%$ smartphone to doing them on printed workbooks

11. Mobile Apps can help me to receive my teacher's online valuable feedback

12. Mobile Apps can help me find relevant resources to my study

13. Mobile Aps can help me communicate English faster anywhere and at anytime 14. Mobile Apps can help me develop my study skills both individually and in groups 15. My main goal of learning English is to be able to

$5 \quad 5$

$2.50 \% \quad 2.50 \%$

25

56

50

57

$8 \quad 11$

$4.00 \% \quad 5.50 \%$

$12.50 \%$

$28.00 \%$

$\begin{array}{ll}65 & 44\end{array}$

(1)

$\begin{array}{llllll}4 & 10 & 15 & 40 & 75 & 56 \\ 2.00 \% & 5.00 \% & 7.50 \% & 20.00 \% & 37.50 \% & 28.00 \%\end{array}$

$\begin{array}{llllll}5 & 5 & 46 & 43 & 71 & 30 \\ 2.50 \% & 2.50 \% & 23.00 \% & 21.50 \% & 35.50 \% & 15.00 \%\end{array}$

$\begin{array}{llllll}3 & 5 & 19 & 52 & 68 & 53 \\ 1.50 \% & 2.50 \% & 9.50 \% & 26.00 \% & 34.00 \% & 26.50 \%\end{array}$

$\begin{array}{llllll}5 & 7 & 27 & 48 & 73 & 40 \\ 2.50 \% & 3.50 \% & 13.50 \% & 24.00 \% & 36.50 \% & 20.00 \%\end{array}$

$\begin{array}{llllll}10 & 1 & 29 & 33 & 78 & 49 \\ 5.00 \% & 0.50 \% & 14.50 \% & 16.50 \% & 39.00 \% & 24.50 \%\end{array}$

$\begin{array}{llllll}2 & 6 & 15 & 51 & 71 & 55 \\ 1.00 \% & 3.00 \% & 7.50 \% & 25.50 \% & 35.50 \% & 27.50 \%\end{array}$
communicate well in English with other people

\begin{tabular}{|c|c|c|c|c|c|c|}
\hline 16. My primary goal of learning & 5 & 3 & 26 & 52 & 71 & 43 \\
\hline English is to succeed in school & $2.50 \%$ & $1.50 \%$ & $13.00 \%$ & $26.00 \%$ & $35.50 \%$ & $21.50 \%$ \\
\hline 17. My primary goal of learning & 2 & 7 & 12 & 48 & 65 & 66 \\
\hline $\begin{array}{l}\text { English is to succeed in my } \\
\text { future studies or career }\end{array}$ & $1.00 \%$ & $3.50 \%$ & $6.00 \%$ & $24.00 \%$ & $32.50 \%$ & $33.00 \%$ \\
\hline
\end{tabular}

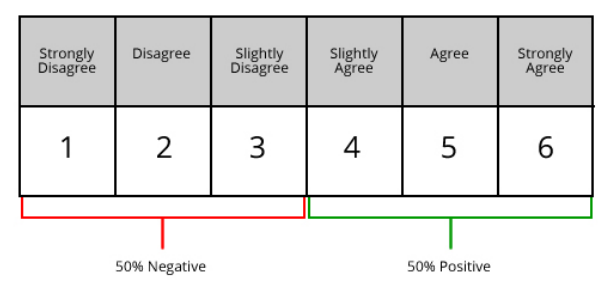

In addition, The mean summary as indicated in table 6 was previously described by the valid percent of the data distribution in table 5 where majority of the respondents subsequently perceive positively as indicated by 4.35 as the 
lowest mean and 4.64 as the high mean according to respondents' choice of slightly agree, agree and totally agree to the items of survey.

Table 6. Mean Summary of Student Perception on Mobile Apps Usage for English Learning Purposes

\begin{tabular}{|c|c|c|c|c|c|c|c|c|c|c|c|}
\hline ITEM & $\begin{array}{l}\text { School } \\
1\end{array}$ & $\begin{array}{l}\text { School } \\
2\end{array}$ & $\begin{array}{l}\text { School } \\
3 \\
\end{array}$ & $\begin{array}{l}\text { School } \\
4\end{array}$ & $\begin{array}{l}\text { School } \\
5 \\
\end{array}$ & $\begin{array}{l}\text { School } \\
6 \\
\end{array}$ & $\begin{array}{l}\text { School } \\
7\end{array}$ & $\begin{array}{l}\text { School } \\
8\end{array}$ & $\begin{array}{l}\text { School } \\
9 \\
\end{array}$ & $\begin{array}{l}\text { School } \\
10 \\
\end{array}$ & $\begin{array}{l}\text { Mean } \\
\text { Ave. }\end{array}$ \\
\hline Q1 & 4.95 & 4.65 & 4.5 & 4.6 & 4.75 & 4.7 & 4.65 & 4.1 & 4.7 & 4.55 & 4.615 \\
\hline Q2 & 5.35 & 4.6 & 5.05 & 4.6 & 4.4 & 4.25 & 4.95 & 4.5 & 4.45 & 4.3 & 4.645 \\
\hline Q3 & 3.6 & 3.75 & 4.95 & 4.5 & 3.95 & 4.95 & 4.9 & 4.1 & 4.5 & 4.6 & 4.38 \\
\hline Q4 & 4.15 & 4.35 & 4.45 & 4.15 & 4.45 & 4.3 & 4.55 & 4.35 & 5.1 & 4.05 & 4.39 \\
\hline Q5 & 3.5 & 4 & 4.5 & 4.4 & 4.2 & 4.2 & 4.2 & 4.1 & 4.4 & 4.2 & 4.17 \\
\hline Q6 & 3.8 & 3.95 & 4.35 & 4.1 & 4.1 & 4.2 & 4.9 & 4.6 & 4.55 & 4.1 & 4.265 \\
\hline Q7 & 4.55 & 4.7 & 4.55 & 4.95 & 4.6 & 4.6 & 5.1 & 4.45 & 4.3 & 4.55 & 4.635 \\
\hline Q8 & 4.9 & 4.7 & 4.3 & 4.1 & 4.6 & 4.55 & 4.65 & 4.95 & 4.5 & 3.9 & 4.515 \\
\hline Q9 & 4.2 & 4.4 & 4.1 & 4.45 & 4.5 & 4.25 & 4.75 & 4.5 & 4.3 & 4 & 4.345 \\
\hline Q10 & 5.35 & 4.75 & 4.3 & 4.3 & 4.7 & 4.75 & 4.8 & 4.6 & 4.7 & 4.75 & 4.7 \\
\hline Q11 & 4.4 & 4.2 & 3.85 & 4.45 & 4.35 & 4.4 & 4.5 & 4.25 & 4.45 & 4.15 & 4.3 \\
\hline Q12 & 5.05 & 4.75 & 5.05 & 4.65 & 4.7 & 4.9 & 4.45 & 4.35 & 4.35 & 4.55 & 4.68 \\
\hline Q13 & 4.65 & 4.6 & 4.6 & 4.6 & 4.65 & 4.1 & 4.5 & 4.1 & 4.5 & 4.55 & 4.485 \\
\hline Q14 & 4.75 & 4.75 & 4.55 & 4.3 & 4.6 & 4.6 & 4.35 & 4.85 & 4.65 & 4.35 & 4.575 \\
\hline Q15 & 4.95 & 5.2 & 5.35 & 4.3 & 4.8 & 4.95 & 4.5 & 4.75 & 4.5 & 4.1 & 4.74 \\
\hline Q16 & 5.05 & 4.2 & 5.05 & 4.75 & 4.15 & 4.1 & 4.2 & 4.95 & 4.5 & 4.55 & 4.55 \\
\hline Q17 & 5.1 & 5.15 & 5.35 & 4.35 & 5 & 5.1 & 4.65 & 4.8 & 4.1 & 4.65 & 4.825 \\
\hline $\begin{array}{l}\text { Total } \\
\text { Mean } \\
\text { Ave. }\end{array}$ & 4.61 & 4.51 & 4.64 & 4.44 & 4.50 & 4.52 & 4.62 & 4.49 & 4.50 & 4.35 & 4.518 \\
\hline
\end{tabular}

\section{Smartphone Applications for Enhancing English Proficiency}

The findings of the study also showed that participants also highlighted the quick access to the any kind of information through these kinds of technologies everywhere and at any time inside the mobile technology.

\section{Most Preferred Smartphone Application Used to Enhance English Language Competence outside School Lesson}

Youtube remained a dominant force in teens' lifestyle in English learning outside classroom, even as Instagram and Snapchat have risen into a prominent role in teens' online academic lives. Asked which platforms they used most often, the overall respondents in this study reported that youtube was the apps they used most frequently (35.50\% said that), followed by Instagram (12\%), and Google translate (9\%), then Snapchat (8\%). 


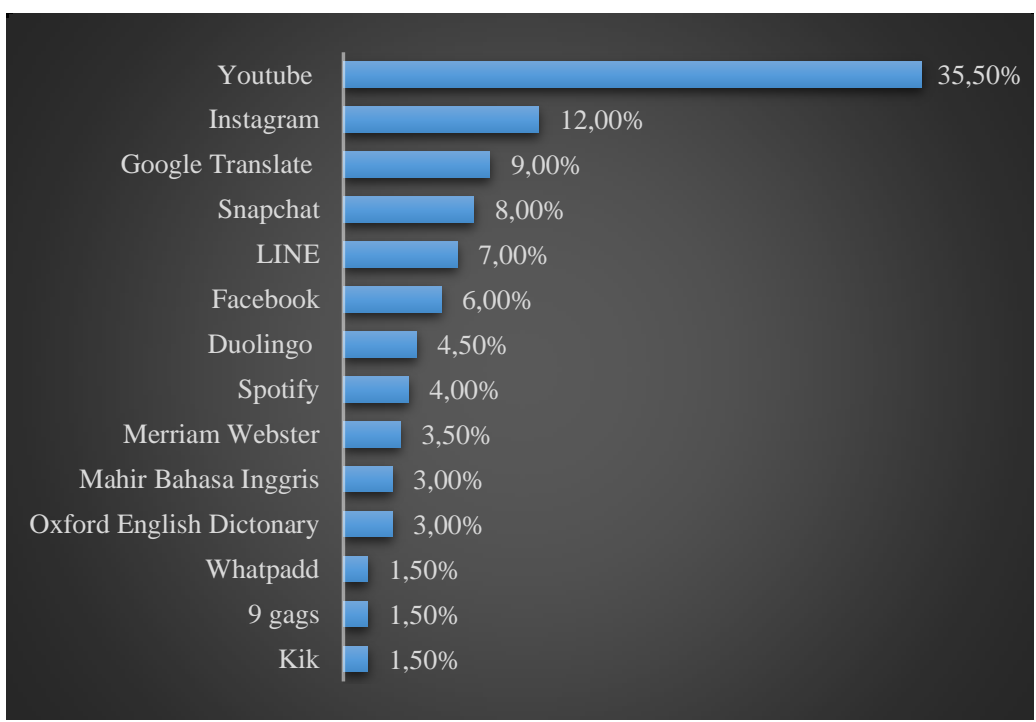

Figure 1: Most Mobile Applications Used to Enhance English Language Competence

\section{Student's Improved Skill of English through Using Smartphone App}

The result of using certain smartphone applications was in general very positive as students were able to improve their vocabulary knowledge and listening comprehension most (see table 7). There were average strong indicators showed 4.78 mean scale for vocabulary aspect and 4.48 mean scale for the speaking skill aspect in a range from 1 to 6 .

Table 7. Student's Improved Skill of English through Using Smartphone Apps

\begin{tabular}{|l|r|r|r|r|r|r|}
\hline Item & \multicolumn{1}{|l|}{ Reading } & Listening & Grammar & Vocabulary & Writing & \multicolumn{1}{l|}{ Speaking } \\
\hline school 1 & 3.05 & 3.35 & 3.25 & 4.1 & 3 & 4.25 \\
school 2 & 3.6 & 3.25 & 2.5 & 4.55 & 2.8 & 4.3 \\
school 3 & 2.7 & 3.45 & 2.3 & 4.9 & 2.85 & 4.8 \\
school 4 & 2.75 & 3.4 & 3.55 & 4.45 & 2.85 & 4 \\
school 5 & 2.95 & 3.55 & 2.7 & 4.75 & 2.45 & 4.6 \\
school 6 & 3.15 & 3.9 & 2.75 & 5.4 & 2 & 3.8 \\
school 7 & 3.2 & 3.5 & 2.35 & 5 & 2.55 & 4.4 \\
school 8 & 3.35 & 3.15 & 1.95 & 4.85 & 3.05 & 4.65 \\
school 9 & 2.35 & 3.7 & 2.35 & 5.35 & 2 & 5.25 \\
school 10 & 2.65 & 3.4 & 2.45 & 4.45 & 3.3 & 4.75 \\
\hline MEAN & $\mathbf{2 . 9 7 5}$ & $\mathbf{3 . 4 6 5}$ & $\mathbf{2 . 6 1 5}$ & $\mathbf{4 . 7 8}$ & $\mathbf{2 . 6 8 5}$ & $\mathbf{4 . 4 8}$ \\
\hline
\end{tabular}

\section{English Language Components Preferred to Learn through Smartphone Apps}

As evident in the below table, the respondents have relatively preferred to learn more on mastering the language components of English which are: vocabulary, listening, and speaking rather than the other ones. The highest mean value is 4.985 in the vocabulary skill, 4.275 as the second highest mean value in the listening skill, and the third highest mean value in the skill. 
Table 8. English Language Components Preferred to Learn through Smartphone Apps

\begin{tabular}{|l|r|r|r|r|r|r|}
\hline Item & Reading & Listening & Grammar & Vocabulary & Writing & Speaking \\
\hline SCHOOL 1 & 2.4 & 4.9 & 3.5 & 5.1 & 1.65 & 3.45 \\
SCHOOL 2 & 2.35 & 4.25 & 3.75 & 4.9 & 1.85 & 3.9 \\
SCHOOL 3 & 2.45 & 4.4 & 2.6 & 4.9 & 1.9 & 4.75 \\
SCHOOL 4 & 2.6 & 4.6 & 3.75 & 4.8 & 1.75 & 3.5 \\
SCHOOL 5 & 2.4 & 4.75 & 3.6 & 5 & 1.5 & 3.75 \\
SCHOOL 6 & 2.2 & 4.3 & 3.6 & 4.5 & 2.3 & 4.1 \\
SCHOOL 7 & 2.5 & 4.8 & 3.35 & 4.9 & 1.75 & 3.7 \\
SCHOOL 8 & 2.35 & 3.1 & 2.8 & 5.2 & 2.7 & 4.85 \\
SCHOOL 9 & 2.5 & 3.9 & 2.75 & 5.35 & 1.7 & 4.8 \\
SCHOOL 10 & 2.85 & 3.75 & 2.6 & 5.2 & 2.1 & 4.5 \\
\hline MEAN & $\mathbf{2 . 4 6}$ & $\mathbf{4 . 2 7 5}$ & $\mathbf{3 . 2 3}$ & $\mathbf{4 . 9 8 5}$ & $\mathbf{1 . 9 2}$ & $\mathbf{4 . 1 3}$ \\
\hline
\end{tabular}

\section{DISCUSSION}

In terms of language learning, it was found that mobile technologies are used by participants for different purposes in terms of language learning and language practicing. These purposes can be listed as follows:

\section{Non-academic Activity at Home or Outside School Lesson.}

The passive skills of English were found in activities i.e.: social media interaction, watching movies or films, and listening to music for entertainment, and some other online relevant activities were indicated to have high exposure on students' smartphone usage. While the active skills of English such as such as checking and replying emails in English, video production and online chats in English were given low attention on students' individual exposure for language learning.

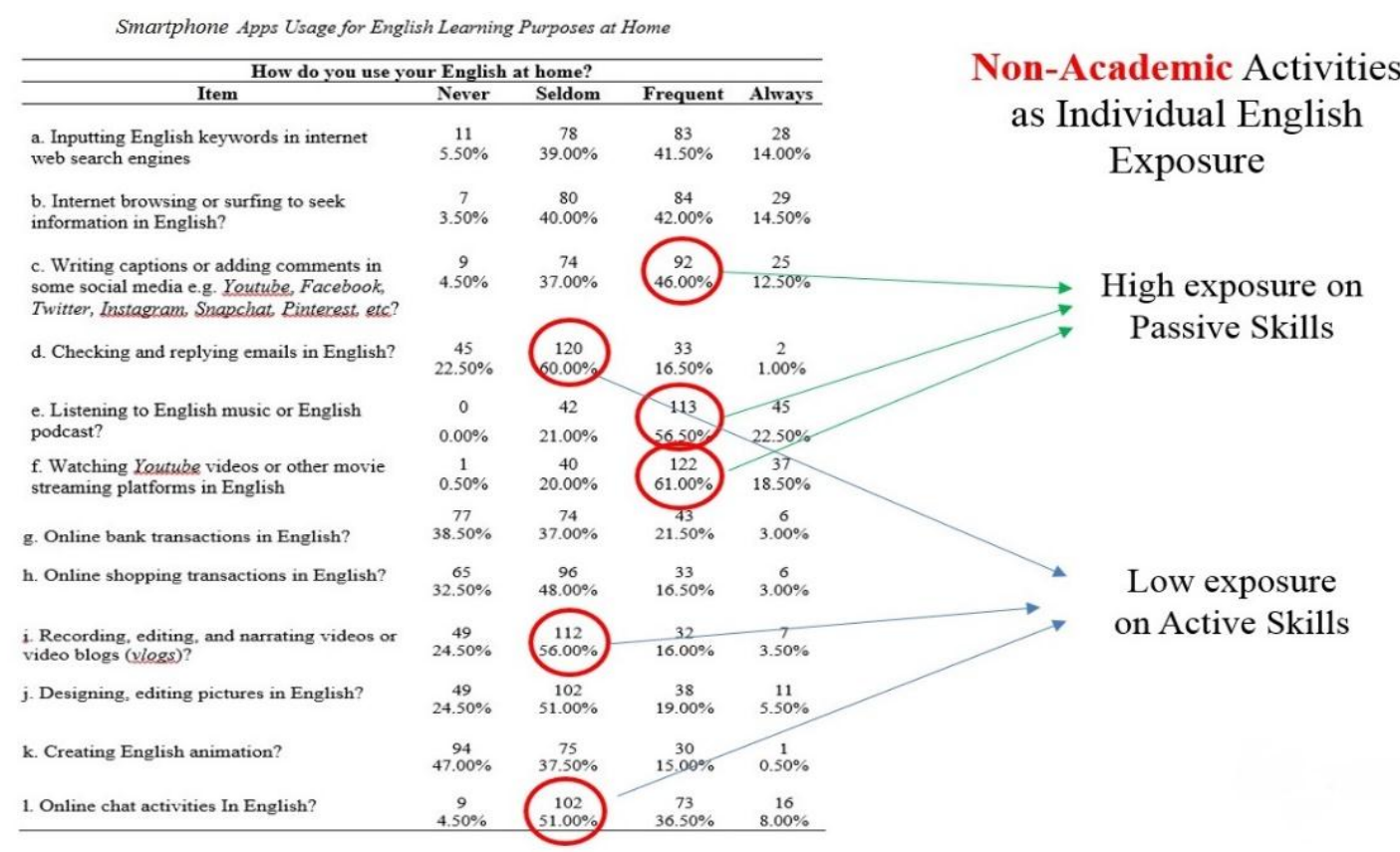




\section{Academic Activity at School}

Playing English lesson games; use of dictionary; listening language learning materials; making topic repetition; listening to music; watching language, etc. The overall results indicated that smartphone technologies were still given a slightly low attention on students' individual exposure for English learning purposes at school. Despite the fact that the smartphone technologies were still used by participants for an educational purpose, the use of smartphone for English learning purposes at school still resulted in lack of effectiveness.

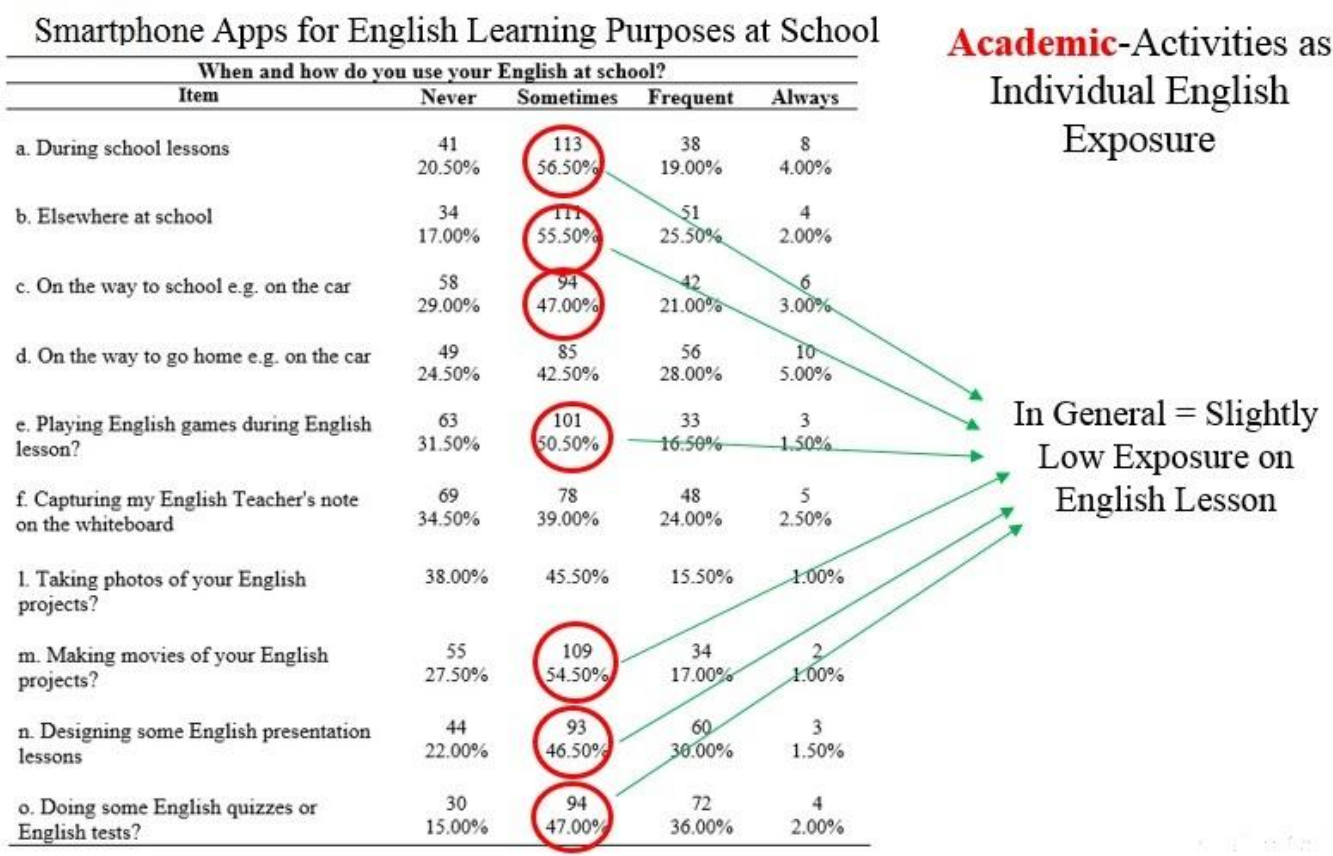

\section{DISCUSSION}

The findings of the present study can be concluded in the following points. First, Indonesian high school students in general, had a positive attitude towards the use of English language in their daily lives both at home and in friendship environment. Despite the high exposure of modern technology possessed at home to sustain their English language exposure, they still insisted that human interaction is the foundation of teaching and learning activities at school. Furthermore, the findings also display a positive perception towards smartphone in learning English either inside or outside the classroom since their overall mean indicated 4.35 as the lowest mean and 4.64 as the high mean according to respondents' choice of slightly agree, agree and totally agree to the items of survey. This finding represents a call from the students to the teachers and curriculum designers to shift from traditional curricula to include new technology in the teaching process which more into learner autonomy.

Second, smartphones are now considered as the window through which the current generation is looking for knowledge and information. Educators are in need to learn how mobile-based informal learning can be integrated into instructed language learning. There are the papers which analyze mobile technology applications on language acquisition in general terms (Rosell-Aguilar, 2007; Fallahkhair et al., 2007; Petersen \& Markiewicz, 2008, Liu et al., 2008; 
Cheng et al., 2010; Abdous et al., 2012; Oberg \& Daniels, 2011; Hsu, 2012), often indicate positive attitudes towards the mobile technology use and suggest better results in terms of language proficiency.

Third, much attention is in need to be paid to the different contexts of formal and informal learning, and how mobile technologies are available and can contribute to the individual's language learning acquisition in these different situations. The mobile technologies are now commonly used by the current generation for different purposes such as gaming, banking, online shopping, and watching TV or films, listening to music, entertainment, taking photos, and PDF viewing by the high school students. This techno-centered concepts focus on technology itself can be used as a means of communication between the learner and the content as well as teacher and learner where a shift from sms-based learning towards the development and use of mobile language learning applications in form of intelligent multimedia tutorial systems is noticeable. In addition, the learning environment theme focuses on theoretical development and practical aspects of such environments.

\section{REFERENCES}

Abdous, M., Facer, B.R., Yen, C.-J. (2012). Academic effectiveness of podcasting: A comparative study of integrated versus supplemented use of podcasting in second language classes. Computers and Education, 58, 43-52.

Barcelon, B. (2010). The life of generation $z$. Retrieved from http://teenlife.blogs.pressdemocrat.com/10220/the-life-of-generation-z/

Cheng, S.-C., Hwang, W.-Y., Wu. S.-Y., Shadiev, R.,\& Xie, C.-H. (2010). A mobile device and online system with contextual familiarity and its effects on English learning on Campus. Educational Technology and Society, 13(3), 93-109

Darmi, R.\& Albion, P. (2014). A Review of Integrating Mobile Phonesfor Language Learning. Paper presented at the 10th International Conference Mobile Learning

Du Plessis, N. (2011). Social Media in Higher Education: The case of Facebook. Vaal University of Technology, North-West University: Vaal Campus. September 2011.

Fallahkhair, S., Pemberton, L., \& Griffiths, R. (2007). Development of a crossplatform ubiquitous language learning service via mobile phone and interactive television. Journal of Computer Assisted Learning, 23, 321-325.

Godwin-Jones, R. (2011). Emerging technologies: Mobile apps for language learning. Language Learning \& Technology, 15(2), 2-11. 85.

Gounder (2011). What is the potential impact of using mobile devices in higher education: Proceedings of SIG GlobDev Fourth Annual Workshop, Shanghai, China: Retrieved from: http://www.globdev.org/files/Shanghai\%20Proceedings/14\%20REVISED\% 20Goundar 20Using\%20Mobile\%20Devices\%20in\%20Education\%20\%20Final.pdf 
Hsu, L. (2012). English as a foreign language learners' perception of mobile assisted language learning: a cross-national study. Computer Assisted Language Learning, 1, 1-17.

Kukulska-Hulme, A. (2009). Will mobile learning change language learning? ReCALL, 21(2), (pp. 157-165).

Kukulska-Hulme, Agnes (2012). Mobile Learning and the Future of Learning. International HETL Review, 2, (pp. 13-18).

Kukulska-Hulme, A., \& Shield, L. (2008). An overview of mobile assisted language learning: From content delivery to supported collaboration and interaction. ReCALL, 20(3), 271-289. doi:10.1017/S0958344008000335, 2028.

Liu, J., Yu, S., Ran, M. (2008). Research in the communicative mobile English learning model. Fifth IEEE International conference of Wireless, Mobile, and Ubiquitous Technologies in Education, DOI 10.1109/WMUTE.2008.26, 60-64.

Oberg, A., \& Daniels, P. (2012). Analysis of the effect a student-centered mobile learning instructional method has on language acquisition. Computer Assisted Language Learning, 1, 1-20.

Palomo-Duarte, M., Berns, A., Dodero, J. M., \& Cejas, A. (2014). Foreign language learning using a gamificated APP to support peer-assessment. In. F. J. García-Peñalvo (Ed.), Proceedings TEEM'14. Second international conference on technological ecosystems for enhancing multiculturality, Salamanca, Spain, October 1st - 3rd, 2014 (pp. 381-386). Salamanca: ACM. doi:10.1145/2669711.2669927

Petersen, S., A., Markiewicz, J.-K. (2008). PALLAS: Personalised Language Learning on Mobile Devices. Fifth IEEE International Conference on Wireless, Mobile, and Ubiquitous Technology in Education, DOI 10.1109/WMUTE.2008.17, 52-59.

Rosell-Aguilar, F. (2007). Top of the pods-in search of a podcasting "podagogy" for language learning, Computer Assisted Language Learning, 20(5), 471492

Russell, M., Bebell, D., O’Dwyer, L., \& O’Connor, K. (2003). Examining teacher technology use: Implications for preservice and inservice teacher preparation. Journal of Teacher Education, 54(4), (pp. 297-310).

Stockwell, G. (2010). Using mobile phones for vocabulary activities: Examining the effect of the platform. Language Learning \& Technology, 14(2), (pp. 95$110 \& 133)$ 